\title{
Phytochemical Investigation and Anti-cancer Activity of Vitex negundo
}

\author{
B. Edwin Jose ${ }^{1 *}$, S.Manikandan², S. Jebaseelan ${ }^{3}$, Dr.R.Meera ${ }^{4}$ \\ ${ }^{1}$ Department of Pharmaceutical Chemistry, Sankaralingam Bhuvaneswari College of Pharmacy, Sivakasi, TN, India. \\ ${ }^{2}$ Department of Pharmaceutics, Sankaralingam Bhuvaneswari College of Pharmacy, Sivakasi, TN, India. \\ ${ }^{3}$ Department of Pharmaceutical Chemistry, Ultra College of Pharmacy, Madurai, TN, India. \\ ${ }^{4}$ Department of Pharmaceutical Chemistry, College of Allied Medical Sciences, Madurai, TN, India. \\ *Corresponding author's E-mail: edwindanekb@gmail.com
}

\begin{abstract}
Received: 10-11-2020; Revised: 25-12-2020; Accepted: 05-01-2021; Published on: 15-01-2021.
\section{ABSTRACT}

Evaluation of anticancer activity of chloroform, ethanol and aqueous extract of Vitex negundo by trypan blue dye exclusion assay against Daltons ascites lymphoma cell lines. In vitro anticancer activity of chloroform, ethanol and aqueous extract of Vitex negundo was evaluated on selected cancerous cells lines trypan blue dye exclusion assay. Trypan blue assay is based on staining of cells. Cells are then counted using heamocytometer under the microscope, non-viable cells were stained blue, viable cells remain unstained. The potent anticancer activity was shown by the methanol extract of Vitex negundo on Daltons ascites lymphoma cell lines. The medicinal plant Vitex negundo was studied by in vitro evaluation methods trypan blue exclusion assay. The chloroform, ethanol and aqueous extract of Vitex negundo have shown potent anticancer activity on selected cancerous cell lines. More efforts are needed to explore potent anticancer plants from the mother earth and save humans around the world from cancer.
\end{abstract}

Keywords: Anticancer activity, chloroform, ethanol and aqueous extract of Vitex negundo, Trypan blue exclusion assay, Daltons ascites lymphoma cell lines.

QUICK RESPONSE CODE $\rightarrow$

DOI:

10.47583/ijpsrr.2021.v66i01.012

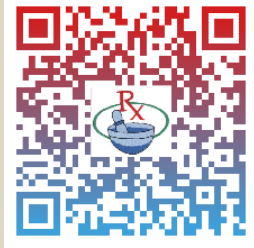

DOI link: $\underline{\text { http://dx.doi.org/10.47583/ijpsrr.2021.v66i01.012 }}$

\section{INTRODUCTION}

ell division in humans is mainly controlled by DNA of the cell. Main factors are responsible for the cause of cancer such as chemical carcinogens, viruses, chromosomal rearrangement or spontaneous transformation, and tumor suppressor genes. Cancer can be caused by any of the three ways improper diet, genetic factors, and environmental factors ${ }^{1,2}$. More than $35 \%$ of all

cancers worldwide are caused by improper diet in the case of colon cancer; diet may account for more than $80 \%$ of the cases. Alcohol and cigarettes to their diet, the percentage cause of cancer may increase to $60 \%$. Plants have been demonstrated clinical source for anticancer compounds. However, many of the plant products and their derivatives are approved for cancer control. Hence, the development of new drugs to play an important role in cancer control is greatly desired ${ }^{3}$.

Vitex negundo Linn (Synonym: Viteex incise Linn, Vitex incise Lam Var hetropylla., family: Verbanaceae). A large, aromatic shrub or sometimes a small slender tree, upto 4.5 $\mathrm{m}$ in height found throughout the greater part of India.
Leaves possess anti-inflammatory, analgesic and antihistamine properties. Roots are used for leprosy, dyspepsia, rheumatism and piles. Bark is used as verminosis and opthalmopathy. Flowers are used in cholera. Fruit used as anthelmintic. The whole plant is used in inflammations, antiseptic, antipyretic and diuretic ${ }^{4-10}$. Earlier studies have shown that the plant possess antiinflammatory and antihistamine ${ }^{11}$, analgesic ${ }^{12}$, antioxidant $^{13}$, antibacterial ${ }^{14}$, CNS depressant ${ }^{15}$, antifungal ${ }^{16}$, snake venom neutralization ${ }^{17}$, mosquito repellant activity $^{18}$, insecticidal ${ }^{19}$, larvicidal efficacy ${ }^{20}$, antinociceptive ${ }^{21}$, antiandrogenic ${ }^{22}$, Hepatoprotective ${ }^{23}$, antifertility $^{24}$, skin aging inhibitor ${ }^{25}$ and anti dopaminergic ${ }^{26}$ effects. Constituents previously isolated from the plant include eight lignans ${ }^{27}$ (negundin $A$, negundin B, 6-hydroxy-4-( 4-hydroxy -3 methoxy)-3hydroxyl methyl -7 methoxy $-3,4$ di hydro 2 napathaldehyde, vitrofolal, (+) - iynoiresinol, (+) iynoiresinol $-3 \alpha-0-\beta-$ Dglucoside, $(+)(-)(-)$ pinorecinol and (+) -diasyringaresinol, irridoid glycoside ${ }^{28}$ (2-p-hydroxy benzoyl mussaenosidic acid), flavonones ${ }^{29}$ (5,3' di hydroxyl $-7,8,4^{\prime}$ trimethoxy flavonone and (5,3' dihydroxy $-6,7,4^{\prime}$ trimethoxy flavonone), flavones ${ }^{30}$ (vitexicarpin), $\beta$ sitosterol $^{31}$, essential oils ${ }^{32}(\alpha$-pinene, linalool, terpinyl acetate, beta caryophyllene ), non diterpene ${ }^{33 .}$ (vitedoin $B$ ), pentacyclic triterpenoids ${ }^{34}$ (beutinilic acid, ursolic acid) and flavonoid glycoside ${ }^{35}$ (luteolin, agnuside, negundoside, iso-orientin). 


\section{MATERIALS AND METHODS}

\section{Collection and identification of plants}

Vitex negundo plant materials were collected from Aritapatti village near Madurai district, in December and was identified by Dr.Stephen, Professor, American college, Madurai, Tamilnadu; a voucher specimen has been deposited at the herbarium unit of the Department of Pharmacognosy, Ultra. College of pharmacy, Madurai, Tamilnadu, India.

\section{Extraction and phytochemical screening of plant}

The powdered plant materials $(500 \mathrm{~g})$ were extracted with petroleum ether at $40-600 \mathrm{C}$, by continuous hot percolation using soxhlet apparatus. The extraction was carried out by using solvent of increasing polarity starting from petroleum ether, chloroform, ethanol and aqueous respectively. The extraction was carried out for 72 hours. The petroleum ether extract was filtered and concentrated to dry mass by using vacumm distillation. A dark greenish brown residue was obtained. The marc left, after petroleum ether extraction was taken and then subsequently extracted with chloroform, ethanol and aqueous for 72 hours. Phyto chemical screening was performed using standard procedure ${ }^{36-38}$.

\section{Preliminary phytochemical investigation}

The qualitative chemical test of various extracts of Vitex negundo was carried out using standard procedure. Terpenoids, Phenolic compounds, Carbohydrates, Tannins, Alkaloids, glycosides, Flavonoids and Phytosterols were present in all the extracts. (Table 1)

Table 1: Phytochemical Screening of Vitex nigundo

\begin{tabular}{|l|c|c|c|c|}
\hline \multicolumn{1}{|c|}{ Extracts } & Petroleum Ether & Chloroform & Ethanol & Aqueous \\
\hline Sterols & - & + & + & - \\
\hline Terpenoids & + & + & + & - \\
\hline Carbohydrates & + & + & + & - \\
\hline Flavonoids & + & + & + & + \\
\hline Proteins & + & - & + & - \\
\hline Alkaloids & - & + & + & + \\
\hline Glycosides & + & + & + & - \\
\hline Tannins & - & + & + & + \\
\hline Saponin & - & - & - & - \\
\hline Phenolic compounds & + & + & + & + \\
\hline Fixed Oil and Fats & + & + & - & - \\
\hline
\end{tabular}

\section{In-vitro cytotoxicity assay}

\section{Trypan Blue}

Trypan blue is a vital stain used to selectively colour dead tissues or cells blue. It is a diazo dye. Live cells or tissues with intact cell membranes are not coloured. Since cells are very selective in the compounds that pass through the membrane, in a viable cell Trypan blue is not absorbed; however, it traverses the membrane in a dead cell. Hence, dead cells are shown as a distinctive blue colour under a microscope. Since live cells are excluded from staining, this staining method is also described as a Dye Exclusion Method ${ }^{39-42}$.

\section{MATERIALS REQUIRED}

DLA (Daltons lymphoma ascites) bearing mice. Phosphate buffered saline (PBS) contains $\mathrm{Nacl}-4 \mathrm{gm}, \mathrm{Na}_{2} \mathrm{HPO}_{4}-0.72 \mathrm{gm}$, $\mathrm{KH}_{2} \mathrm{PO}_{4}$ - 0.1gm, $\mathrm{KCl}-0.1 \mathrm{gm}$ and Distilled water- $500 \mathrm{ml}$. The dye used is Trypan blue and the cell is counted by using Haemocytometer.

\section{PROCEDURE}

The tumour cells aspirated from the peritoneal cavity of tumour caring mice were washed thrice with normal saline and checked for ability using tryphan blue dye exclusion method. The cell suspension $\left(1 \times 10^{6}\right.$ cells in $\left.0.1 \mathrm{ml}\right)$ was added to tubes maintaining various concentrations of the test compounds and the volume was made up to $1 \mathrm{ml}$ using phosphate buffered saline (PBS) control tubes contained only cell suspension. These assay mixtures were incubated for 3 hours at $37^{\circ} \mathrm{C}$ and percent of dead cells were evaluated by trypan blue exclusion method.

\section{Number of dead cell}

$\%$ Cytotoxicity = ------------------------ $\times 100$

Number of life cell + Number of dead cell

\section{Statistical analysis}

All data were presented as means of percentage inhibition. Statistical analysis for all the assays results were done using Microsoft Excel program. 
Table 2: Cytotoxicity of Chloroform Extract of "Vitex negundo" to Dalton's Lymphoma Ascites Carcinoma (DLA) Cells

\begin{tabular}{|c|c|}
\hline Concentration $\boldsymbol{\mu g} / \mathbf{m l}$ & \begin{tabular}{c} 
Percentage of Cytotoxicity \% \\
\hline $200 \mu \mathrm{g}$
\end{tabular} \\
\hline $100 \mu \mathrm{g}$ & $100 \%$ \\
\hline $50 \mu \mathrm{g}$ & $100 \%$ \\
\hline $20 \mu \mathrm{g}$ & $41 \%$ \\
\hline $10 \mu \mathrm{g}$ & $16 \%$ \\
\hline
\end{tabular}

Table 3: Cytotoxicity of Ethanol Extract of "Vitex negundo" to Dalton's Lymphoma Ascites Carcinoma (DLA) Cells

\begin{tabular}{|c|c|}
\hline Concentration $\boldsymbol{\mu g} / \mathrm{ml}$ & Percentage of Cytotoxicity \% \\
\hline $200 \mu \mathrm{g}$ & $100 \%$ \\
\hline $100 \mu \mathrm{g}$ & $100 \%$ \\
\hline $50 \mu \mathrm{g}$ & $38 \%$ \\
\hline $20 \mu \mathrm{g}$ & $15 \%$ \\
\hline $10 \mu \mathrm{g}$ & $6 \%$ \\
\hline
\end{tabular}

Table 4: Cytotoxicity of Aqueous Extract of "Vitex negundo" to Dalton's Lymphoma Ascites Carcinoma (DLA) Cells

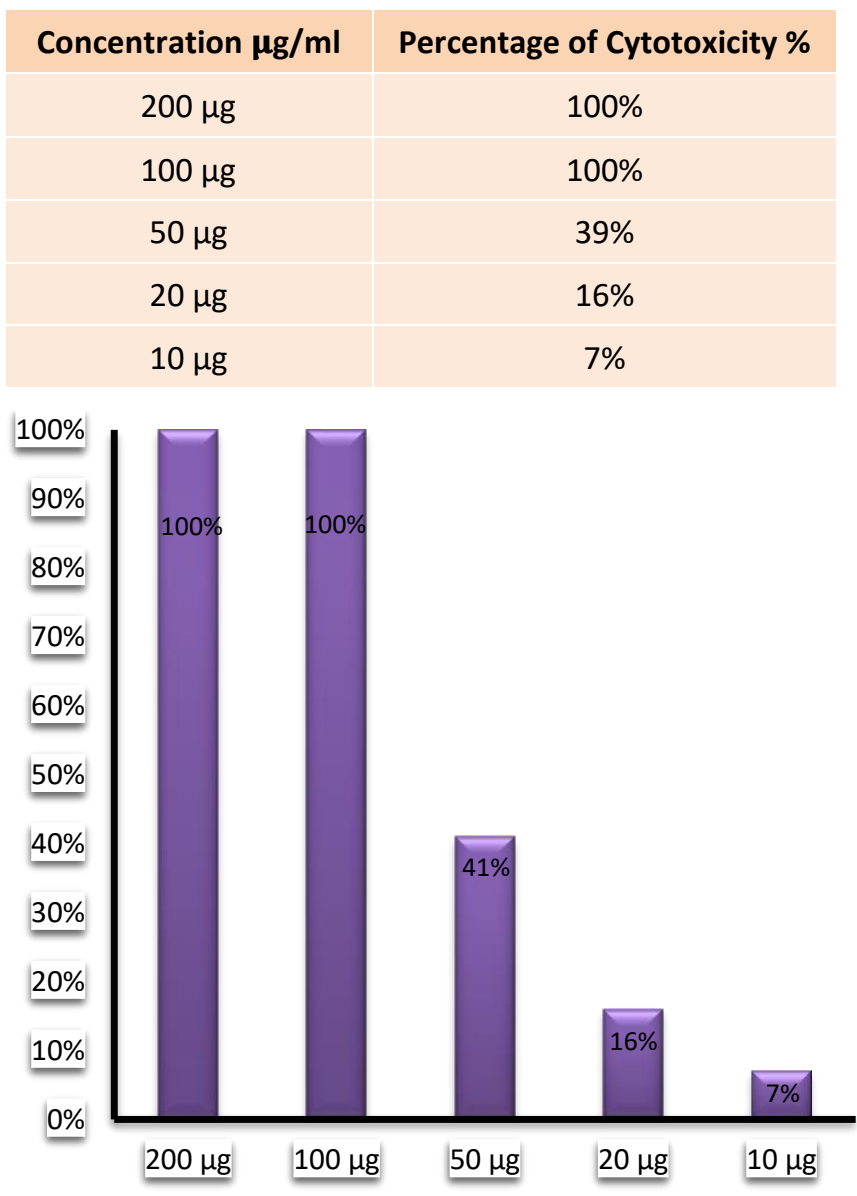

Figure 1: Cytotoxicity of Chloroform Extract of "Vitex negundo" to Dalton's Lymphoma Ascites Carcinoma (DLA) Cells

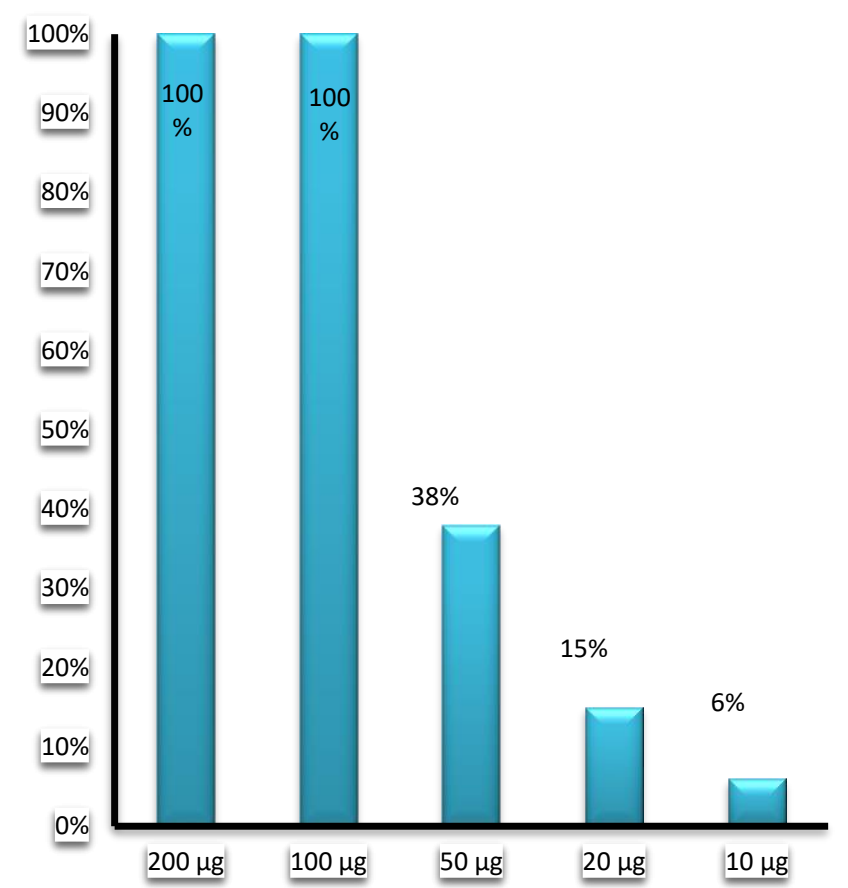

Figure 2: Cytotoxicity of Ethanol Extract of "Vitex negundo" to Dalton's Lymphoma Ascites Carcinoma (DLA) Cells

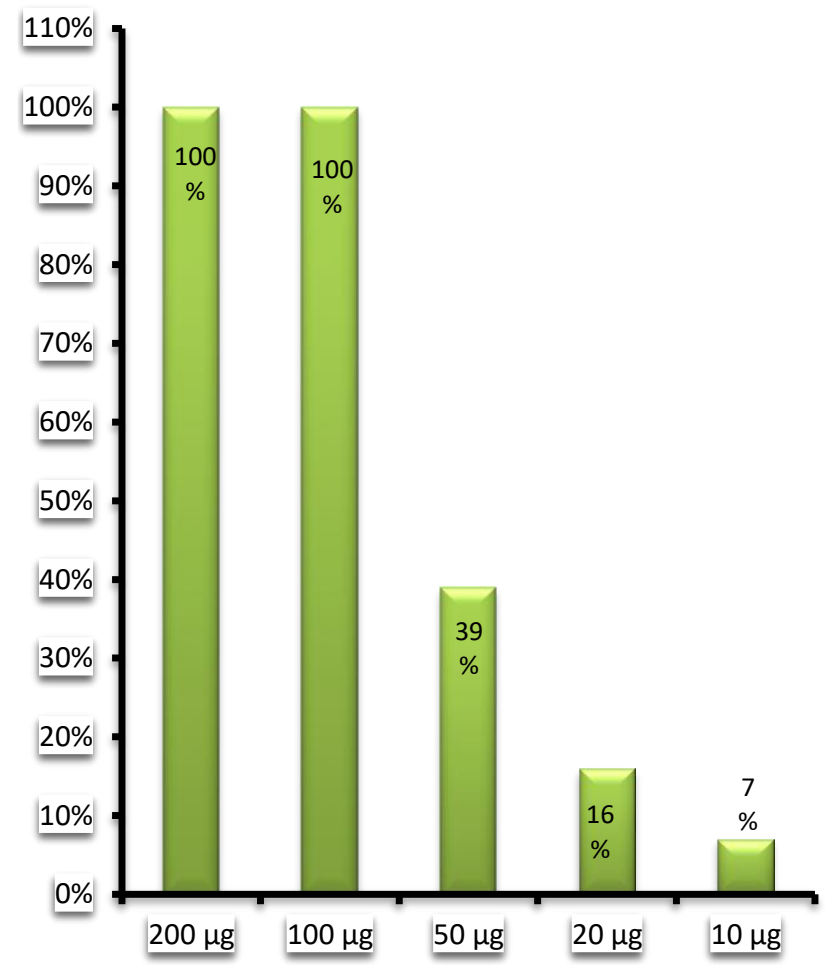

Figure 3: Cytotoxicity of Aqueous Extract of "Vitex negundo" to Dalton's Lymphoma Ascites Carcinoma (DLA) Cells

\section{RESULTS AND DISCUSSION}

The ethanolic extract of leaves of Vitex negundo was tested against DAL cell lines. Different concentration of plant extract was inoculated with selected cell line and the cytotoxicity was assessed using trypan blue dye exclusive. 
The test based on the principle that the dead cell accepts dye and stain with blue color. The plant drug may disturb the membrane integrity and caused the cell death, which is one of the hall marks of apoptosis. The Chloroform, Ethanol and Aqueous extracts showed $100 \%$ of cytotoxicity against DAL cell line.

The phytochemical investigation shows the presence of Flavanoids, carbohydrates, steroids and alkaloids and phenolic compounds in the extract. The Chloroform, Ethanol and Aqueous extracts were subjected to invitro cytotoxicity studies at $50 \mu \mathrm{g}, 100 \mu \mathrm{g}, 200 \mu \mathrm{g}$ concentrations using PBS and DLA cells (Table 2,3,4). The Chloroform, Ethanol and Aqueous extracts showed 100\%, 100\% and $100 \%$ cytotoxicity respectively (Fig 1,2,3). The extracts of Petroleum ether, chloroform, Ethanol and Aqueous extracts have significant cytotoxicity activity.

\section{CONCLUSION}

The plant was initially selected and tested for anticancer activity based on their historical and other traditional uses. The root extract of Vitex negundo Chloroform, Ethanol and Aqueous extracts were prepared and tested for their potential as anticancer activity by in-vitro evaluation method, i.e., trypan blue exclusion assay. This was done by closely monitoring the viability of cultured human cells exposed to the plant extracts. More efforts are needed to explore potent anticancer plants from the mother earth and save humans around the world from cancer.

\section{REFERENCES}

1. World Health Organization, WHO Programmes and Projects: Cancer, (2009). Available from: http://www.who.int/cancer/en/. [Last accessed on 2013 July 10].

2. Mongelli E, Pampuro S, Coussio J, Salomon H, Ciccia G. Cytotoxic and DNA interaction activities of extracts from medicinal plants used in Argentina. J Ethnopharmacol .2000;71(1-2):145-51.

3. Younes RN, Varella AD, Sufredini IB. Selecao extracaoe identificac, aodedrogas novas anti-cancer de plantas brasileiras. Acta Oncol Bras .2000;20:15.

4. The Wealth of India. A Dictionary of Indian Raw Materials and Industrial Products .2002; X: 522-524.

5. Warrier PK, Orient Blackswan VPK. Materia medica, Vegetable Indian Medicinal Plants. 1993;5: 387.

6. Dictionary of Indian Medicinal Plants. Central Institute of Medicinal and Aromatic Plants, Lucknow,1992.

7. Kirthikar KR and Basu .Indian MedicinalPlants.1: 1937-1940.

8. Chopra RN, Nayar SL, Chopra IC. Glossary of Indian Medicinal Plants.1956; 5: 257.

9. Gamble JS (James Sykes), Flora of the Presidency of Madras Gamble. London :West, Newman and Adlard,1915-2:11011102.

10. Deni Bown. The Royal Horticultural Society, Encyclopedia of Herbs and their uses. Dorling Kindersley, London, 2002,221-371.
11. Dharmasiri MG, Jayakody JR, et al. Anti-inflammatory and analgesic activities of mature fresh leaves of Vitex negundo. Journal of Ethnopharmacology.2003;2-3: 199-206.

12. Telang RS, Chatterjee $S$, et al. Study on analgesic and antiinflammatory activities of Vitex negundo Linn. Indian Journal of Pharmacology. 1999;31: 363-366.

13. Om Prakash Tiwari, Yamini B, Tripathi. Antioxidant properties of different fractions of Vitex negundo Linn. Food Chemistry. 2007;100: 1170-1176.

14. Perumalsamy $\mathrm{R}$, Ignacimuthu $\mathrm{S}$, et al. Screening of 34 Indian medicinal plants for antibacterial properties. Journal of Ethnopharmacology.1998; 62: 173-182.

15. Ravishankar B,Nair BR, Sasikala CK.Pharmacological evaluation of Vitex negundo leaves. Bull. Med. Ethnobot. Res. 1985; 6(1): 72-92.

16. Sanjay Guleria, Ashok Kumar. Antifungal activity of some Himalayan medicinal plants using direct bioautography. Journal of Cell and Molecular Biology.2006;95-98.

17. 17.Alam MI, Gomes A. Snake venom neutralization by Indian medicinal plants (Vitex negundo and Emblica officinalis) root extracts. Journal of Ethnopharmacology. 2003;86(1): 75-80.

18. Hebblkar DS, Hebbalkar GD, et al. Mosquito repellent activity of oils from Vitex negundo Linn, leaves. Indian Journal Med. Res. 1992;95:200-203.

19. Desmukh PB, et al. Study of insecticidal activity of twenty indigenous plants .Pesticides. 1982; 16(2): 7-10.

20. Gupta RK, Tandon VR. Antinociceptive activity of Vitexnegundo Linn leaf extract. Indian Journal of Physiol.Pharmacol.2005; 49(2): 163-70.

21. Bhatgava SK. Antiandrogenic effects of a flavonoid-rich fraction of Vitex negundo seeds: A histological and biochemical study in dogs. Journal of Ethnopharmacology.1989; 27(3): 327-339.

22. Avadhoot $Y$, Rana AC. Hepatoprotective effect of Vitex negundo against carbon tetrachloride-induced liver damage.Arch.Pharm.Res.1991;14(1): 96-98.

23. Bhargava, S.K. .Anti-fertility effect of the flavonoids (VI-VII) of Vitex negundol L seeds in male dogs. J. Plant. Med. Phylother.1986; 20 (2): 188-198.

24. Chiba Katsuyoshi, et al. Compositions for retarding skin aging Patent Abstract of Japan.2002;

25. Sadekar SS, Chauhan VB, et al. Antidopaminergic Activity of Vitex negundo Linn Leaves. Journal of Natural Remedies.2006;6(2): 165-169.

26. Azar-ul-Haq, Malik A, Khan M.T,H. et al. Tyrosinase inhibitory lignans from the methanol extract of the roots of Vitex negundo Linn. and their structure-activity relationship. Phytomedicine.2006;(13)255-260.

27. Sehgal CK, Taneja KL, Dhar. 2'-p-Hydroxybenzoyl Mussaenosidic Acid, a New Iridoid Glucoside from Vitex negundo. Phytochemistry. 1982;21(2): 363-366. 
28. Basudeb Achari Uday S, Chowdhury Pradeep K, Dutta Satyesh C, Pakrashi. Two isomeric flavanones from vitex negundo. Phytochemistry.1984;23(3):703-704.

29. Fredyc Diaz, Daniel chavez, et al. Cytotoxic flavone analogues of Vitexicarpin, a constituent of the leaves of Vitex negundo. Journal of Natural Product.2003;66: 865-867.

30. 30. Taralkar SV, Chattopadhay S, et al. Chem. Engg.Dept.,Dr. Babasaheb Ambedkar Tech.University, Lonere-402103. Rajgad,Maharashtra.

31. Pan JG, Xu ZL, Fan JF, et al. Zhongguo Zhong Yao Za Zhi. 1989;14(6):357-9,383.

32. Ono $M$, Nisidha $Y$, Masuoka C, Li JC, Okawa M, Ikeda $T$, Nohara T. Lignan derivatives and a norditerpene from the seeds of Vitex negundo. J.Nat.Product.2004;67(12): 2073-5.

33. Chandramu C, Manohar RD. Isolation, characterization and biological activity of betulinic acid and ursolic acid from Vitex negundo L. Phytother Res.2003;17(2):129-134.

34. Elango V, Ambujavalli L. Pharmacological and microbiological studies on Pergularia extensa. Fitoterapia. 1985;56,300.

35. Davies LL, Raventos J, Walpole AL. A method for the evaluation of analgesic activity using rats. Brit.J.Pharmacy.1946;1,246-255.
36. Sofowora A. Medicinal plants and Traditional Medicine in Africa. Spectrum books Ibadan.1993;150.

37. Trease GE, Evans WC. Pharmacognosy. $11^{\text {th }}$ edn.Bailliere Tindall, London,1978;176-180.

38. Harbone JB, Phytochemical Methods. Chapman and Hall Ltd, London, UK.(1st eds). 1973;49-188.

39. Priya VP, Radhika K, Rao SA. In vitro anti-cancer activity of aqueous and acetone extracts of Tridax procumbens leaf on PC 3 cell lines. Int J Pharm Pharm Sci 2011;3(4):1-4.

40. Ramamurthy SK, Pittu VP, Kotturi R, Devi P, Kumar S. In vitro cytotoxic activity of methanol and acetone extracts of Parthenium hysterophorus flower on A549 cell lines. Int J Pharm Sci Review and Research, 2011;10(2):95-9.

41. Prasanth NY, Dilip C, Sanaldev KT, Lisaugustine, Saraswathi R. Evaluation of invitro cytotoxic and antioxidant activities of Ipomoea batatas. International journal of pharmacy and pharmaceutical sciences, 2010;2(3):91-92.

42. Jayaseelan RS, Fijesh P Vijayan, Mathesvaran M, Suresh V, Jose Padikkala. cytotoxic and antitumor activity of methonolic extracts Desmodium triangulare (retz) merr. Root. International journal of pharmacy and pharmaceutical sciences, 2012;4(3):540-542.

Source of Support: None declared.

Conflict of Interest: None declared.

For any question relates to this article, please reach us at: editor@globalresearchonline.net New manuscripts for publication can be submitted at: submit@globalresearchonline.net and submit_ijpsrr@rediffmail.com 